\title{
The Impact of Social Media on Panic During the COVID-19 Pandemic in Iraqi Kurdistan: Online Questionnaire Study
}

\author{
Araz Ramazan Ahmad ${ }^{1,2^{*}}$, MA, PhD; Hersh Rasool Murad ${ }^{3 *}$, MA, PhD \\ ${ }^{1}$ Department of Administration, College of Humanities, University of Raparin, Ranya - Al Sulaimaniyah, Iraq \\ ${ }^{2}$ Department of International Relations \& Diplomacy, Faculty of Administrative Sciences and Economics, Tishk International University, Erbil, Iraq \\ ${ }^{3}$ Department of Public Relations \& Marketing, Technical College of Administration, Sulaimani Polytechnic University, Sulaimani, Iraq \\ *all authors contributed equally
}

\section{Corresponding Author:}

Araz Ramazan Ahmad, MA, PhD

Department of Administration

College of Humanities

University of Raparin

Main Road

Ranya - Al Sulaimaniyah, 46012

Iraq

Phone: 9647701573122

Email: araz.ahmad85@uor.edu.krd

\begin{abstract}
Background: In the first few months of 2020, information and news reports about the coronavirus disease (COVID-19) were rapidly published and shared on social media and social networking sites. While the field of infodemiology has studied information patterns on the Web and in social media for at least 18 years, the COVID-19 pandemic has been referred to as the first social media infodemic. However, there is limited evidence about whether and how the social media infodemic has spread panic and affected the mental health of social media users.

Objective: The aim of this study is to determine how social media affects self-reported mental health and the spread of panic about COVID-19 in the Kurdistan Region of Iraq.

Methods: To carry out this study, an online questionnaire was prepared and conducted in Iraqi Kurdistan, and a total of 516 social media users were sampled. This study deployed a content analysis method for data analysis. Correspondingly, data were analyzed using SPSS software.

Results: Participants reported that social media has a significant impact on spreading fear and panic related to the COVID-19 outbreak in Iraqi Kurdistan, with a potential negative influence on people's mental health and psychological well-being. Facebook was the most used social media network for spreading panic about the COVID-19 outbreak in Iraq. We found a significant positive statistical correlation between self-reported social media use and the spread of panic related to COVID-19 $(R=.8701)$. Our results showed that the majority of youths aged 18-35 years are facing psychological anxiety.

Conclusions: During lockdown, people are using social media platforms to gain information about COVID-19. The nature of the impact of social media panic among people varies depending on an individual's gender, age, and level of education. Social media has played a key role in spreading anxiety about the COVID-19 outbreak in Iraqi Kurdistan.
\end{abstract}

(J Med Internet Res 2020;22(5):e19556) doi: $10.2196 / 19556$

\section{KEYWORDS}

social media; COVID-19; infodemic; panic; mental health; fake news; misinformation; impact; Kurdistan region; Iraq 


\section{Introduction}

\section{Background}

The coronavirus disease (COVID-19) is an infectious disease caused by a newly discovered coronavirus [1]. Cases of COVID-19 first emerged in late December 2019, when a mysterious illness was reported in Wuhan, China. The cause of the disease was soon confirmed as a novel coronavirus, and the infection has since spread to many countries worldwide and has become a pandemic disease [2]. Several websites have published information about COVID-19 and have given different instructions to their users about ways to prevent the spread of the virus, such as keeping a distance between themselves and others, using masks, and washing their hands [3]. Social media has become a source of disseminating information to the public. Many individuals will experience isolation during hospitalization or when quarantining at home [4]. Social media can be an efficient source of information and an effective means for staying abreast of the vast amount of medical knowledge [5].

\section{COVID-19 Cases in Iraqi Kurdistan}

Prior to the outbreak of COVID-19, people already relied on social media to gather information and news, and since the outbreak in December 2019, people in many countries have relied on social media to obtain information about the virus. In addition, people in Iraqi Kurdistan depend on social media. Internet use is strongly associated with behaviors related to health information; users write about their health on various social media platforms [6]. According to Kemp [7], there were 29.82 million internet users and 21 million social media users in Iraq in January 2020. Therefore, internet data, including data from social media platforms such as Twitter, have been used extensively in the past 20 years to study health patterns and better understand infectious disease outbreaks, a field known as infodemiology or (if used as surveillance tool) infoveillance [8].

At the time of writing, the global spread of COVID-19 is still a rapidly evolving situation. The Kurdistan Regional Government (KRG) created a webpage [9], which is regularly updated by the Ministry of Health, to communicate information about COVID-19 cases in Kurdistan. According to government statements, only the Ministry of Health or the World Health Organization (WHO) is qualified to confirm COVID-19 cases in Iraqi Kurdistan. Nevertheless, most people rely on social media and look for information on social media platforms instead of using the official KRG webpage.

According to statements from the KRG's Ministry of Health, as of April 10, 2020, the total number of confirmed cases is 324, including 3 deaths, 134 recovered patients, and 187 active cases [9]. The main objective of this early study is to investigate the relationship between using social media platforms and the spreading of panic during this COVID-19 outbreak.

\section{Literature Review}

The first study on social media during a pandemic dates back to the $2009 \mathrm{H} 1 \mathrm{~N} 1$ pandemic, tracking the prevalence of misinformation (determined as 4.5\%), terminology use ("H1N1" versus "swine flu"), public sentiments and fear, and relationships between case incidence and public concern [10]. Previous studies used the internet to collect data related to diseases, such as the search frequency of hand washing, hand sanitizer, and antiseptic topics [11]. The WHO declared that they are currently fighting not only an international epidemic but also a social media infodemic, with some media claiming that the coronavirus is the first true social media infodemic because it has accelerated information and misinformation worldwide and is fueling panic and fear among people [12]. This is an unproven but testable hypothesis, because users of social media use the platforms to express their emotions, feelings, and thoughts, which can be a valuable source of data for researching mental health [13].

ABC News reported a poll claiming that in the age of social media, anxiety about the coronavirus spreads faster than the virus itself, resulting in public panic worldwide [14]. On the other hand, social media is also a practical platform for the spreading of public health messages to audiences [15].

Brewer on BBC News [16] posits that hearing a lot of information and news about COVID-19 has affected the public and created panic, causing people to live with anxiety. Similarly, Rothschild and Fischer [17] claimed that social media is spreading fear and panic among social media users. Correspondingly, in the discussion on social media, Cellan-Jones [18] stated that people depend on social media to gain information and facts about COVID-19, as some countries use filters, which is why social media gives some information but not all the facts.

After COVID-19 appeared and was transmitted to other countries outside of Mainland China, people turned to social media to know more about the virus. According to Molla [19], in just 24 hours, there were 19 million mentions of COVID-19 across social media and news sites worldwide.

The mass media has been called on to take responsibility for providing correct information and aiding comprehension among citizens [20]. Frenkel et al [21] reports that after the WHO claimed that social media companies were fueling misinformation on COVID-19 worldwide, some social media companies tried to remove false information from their platforms.

Victor [22] claims that in today's digital age, Chinese citizens could not get enough facts about COVID-19, which is why they depended on social media and widely shared their information, photos, and videos, sometimes inaccurately. Likewise, in India, the government has asked top social media companies like Facebook, YouTube, TikTok, ShareChat, and Twitter to stop publishing misinformation, as it creates panic among people. Similarly, Emmott [23] noted that, according to a European Union document, Russian media has published a "significant disinformation campaign" about the COVID-19 outbreak to create panic among the public in Western countries.

In a contemporary discussion on the effects of media, one researcher [24] stated that in some countries, social media impacted the buying crisis, when many people tried to buy toilet paper and other items because of the spreading fear of COVID-19 on social media. According to the newspaper The Star [25], social media is responsible for much of the panic 
surrounding COVID-19, internationally leading to a situation where social media companies tried to eradicate posts about COVID-19 from their platforms. Furthermore, Devlin [26] stated that people saw posts of empty shops on social media, which created panic related to food shortages. Additionally, Kent [27] noted that social media gave everyone the chance to share information with everyone else, which is why people posted on social media as soon as they heard something about COVID-19. In addition, it is noted that publishing inaccurate information on social media networks about the spread of diseases will have a negative impact on public health and people's mental health [28]. The public sphere in the 21st century has undergone a transformation generated by the adoption of online communication technologies. New media has become an important source of health information and a platform for discussing personal experiences, opinions, and concerns regarding health, illnesses, and treatment [28]. Similarly, Dillon [29] noted that people spend a lot of time on social media and may see cases of panic buying in various countries during the COVID-19 pandemic, which can spread panic further. In addition, El-Terk [30] showed that nowadays everyone is an expert because everyone tries to have a voice and send a message about COVID-19. Correspondingly, Garrett [31] explained that we gave power to social media to create fear about COVID-19, as we all publish panic-inducing information and it circulates.

Merchant and Lurie [32] found that at present, due to the development of social media, many methods of communicating and disseminating information and news are available to the public. These are fast and effective and can spread true information as well as misinformation. In addition, La et al [33] said that many countries did not circulate information to the public about the COVID-19 outbreak or were unable to provide the public with the information they needed; thus, people relied on the information they could find on social media. The Vietnamese case is a successful example of dealing with social media in the right way. The country's Ministry of Health created accounts on social media networks, and through those accounts, they published information about COVID-19 to the public.

Mian and Khan [34] argue that there has been a worldwide increase in the spread of fake news and misinformation about COVID-19, with misinformation such as the lab theory on the origin of the virus allegedly "originating" on social media. Correspondingly, Petric and others $[35,36]$ believe that "media coverage has highlighted COVID-19 as a unique threat, rather than one of many, which has added to panic, stress." Depoux and others [37-40] determined that social media has played three main roles in the COVID-19 outbreak in most countries. First, facts about the outbreak were published on social media. Second, misinformation, fake news, and inaccurate information about the outbreak was published on social media. Third, social media created fear and panic about the outbreak worldwide.

Little or no evidence is available on the perception and impact of social media during this pandemic, in particular within non-Western communities such as Iraqui Kurdistan.

\section{Methods}

In this study we used a quantitative survey methodology to obtain data from Kurdish social media users. The questionnaire was prepared in the Kurdish language, and 516 social media users were sampled to collect the data. A descriptive content analysis was used to analyze the data. SPSS Version 25 (IBM Corp) was used to categorize and test the results. The social media users participated in a random online questionnaire, which aimed to determine the impact of social media on the spreading of panic about the COVID-19 outbreak, as well as social media's impact on people's mental health and the health crisis facing countries worldwide.

\section{Results}

Table 1 indicates that, of 516 study participants, 294 (57\%) were male and $222(43 \%)$ were female. In addition, most of the participants $(n=336,65.1 \%)$ were aged $18-35$ years. Those who were 51 years and older made up only $6 \%(n=31)$ of the participants. The participants were divided into nine categories based on their scientific qualification. The most common scientific qualification was a Bachelor degree $(n=261,50.6 \%)$, while the least common one was a higher diploma $(n=3,0.6 \%)$.

The first question in this study asked participants "Which social media platform do you use to get news and information about COVID-19?" As shown in Table 2, the majority of participants $(426 / 516,82.6 \%)$ used Facebook to acquire information about COVID-19. The platforms TikTok, Skype, WeChat, and Myspace were among the lowest used for news and information. Facebook is at the top because it is the most popular social media platform used in the Kurdistan Region of Iraq.

The second question was "What news topics have you mostly heard/seen/read on social media during these three months of 2020?" As shown in Table 3, the highest proportion of participants $(n=394,76.4 \%)$ had heard, seen, or read health news (COVID-19), while the lowest proportion of participants had heard, seen, or read technology news $(n=3,0.6 \%)$. The survey results of the 516 participants show that the COVID-19 health crisis is affecting the type of news topics most commonly followed on social media. 
Table 1. Sociodemographic variables of study participants $(\mathrm{N}=516)$.

\begin{tabular}{ll}
\hline Variables & Participants, $\mathrm{n}(\%)$ \\
\hline Gender & $294(56.9)$ \\
Male & $222(43.0)$ \\
Female & \\
Age (years) & $336(65.1)$ \\
$18-35$ & $149(28.9)$ \\
$36-50$ & $31(6.0)$ \\
$\geq 51$ & \\
Scientific qualifications & $43(8.3)$ \\
PhD & $85(16.5)$ \\
Master of Arts & $3(0.6)$ \\
Higher diploma & $261(50.6)$ \\
Bachelor & $65(12.6)$ \\
Diploma & $35(6.8)$ \\
High school & $11(2.1)$ \\
Secondary school & $7(1.4)$ \\
Primary school & $6(1.2)$ \\
Just reading and writing &
\end{tabular}

Table 2. The social media platforms used to get news about the coronavirus disease.

\begin{tabular}{ll}
\hline Social media platforms & Participants $(\mathrm{N}=516), \mathrm{n}(\%)$ \\
\hline Facebook & $426(82.6)$ \\
Instagram & $33(6.4)$ \\
Twitter & $17(3.3)$ \\
Snapchat & $2(0.4)$ \\
YouTube & $10(1.9)$ \\
TikTok & $1(0.2)$ \\
LinkedIn & $6(1.2)$ \\
WhatsApp & $3(0.6)$ \\
Telegram & $4(0.8)$ \\
Skype & $1(0.2)$ \\
Viber & $9(1.7)$ \\
LINE & $2(0.4)$ \\
WeChat & $1(0.2)$ \\
VKontakte (VK) & $0(0.0)$ \\
Badoo & $0(0.0)$ \\
Myspace & $1(0.2)$ \\
\hline
\end{tabular}


Table 3. The news topics classifications.

\begin{tabular}{ll}
\hline News topics & Participants $(\mathrm{N}=516), \mathrm{n}(\%)$ \\
\hline Social news & $14(2.7)$ \\
Health news $\left(\mathrm{COVID}-19^{\mathrm{a}}\right)$ & $394(76.4)$ \\
Technology news & $3(0.6)$ \\
Economic news & $10(1.9)$ \\
Sports news & $4(0.8)$ \\
Miscellaneous news & $65(12.6)$ \\
Political news & $20(3.9)$ \\
Cultural news & $6(1.2)$ \\
\hline
\end{tabular}

${ }^{\mathrm{a}}$ COVID-19: coronavirus disease.

Cronbach alpha was used to determine the reliability of the study; its value was .825 and the validity was 0.753 , indicating that the study questionnaire is highly reliable. Reliability refers to the accuracy, dependability, stability, and consistency of the research instrument. The recommended appropriate sample size is "approximately 200 individuals (or more) for a research" [41] indicating that the sample size of 516 respondents in this study was appropriate.

Table 4 shows the data on repeat distributions (mean, standard deviation, coefficient of variation, and relative importance) and indicates the explanatory variables that focus on Questions 3, 5,6 , and 8 .

Table 5 shows the responses of 516 people to the question "If your answer to the sixth question is Yes, how did that fear affect you?" As shown in the table, $38.6 \%(n=199)$ of the participants were psychologically affected, while $36.0 \%(n=186)$ stated that they were not afraid. A minority stated that they were physically affected $(n=9,1.7 \%)$. The responses of the 516 participants showed that fear was primarily a psychological response that could cause a reduction in physical immunity, which is one of the reasons for poor outcomes when infected with COVID-19.

Table 4. Descriptive statistics of questions.

\begin{tabular}{llll}
\hline Questions & Value, mean (SD) & Coefficient of variation & Relative importance \\
\hline $\begin{array}{l}\text { Question 3: Do you think that publishing more news related to COVID- } \\
\text { 19 }\end{array}$ & $2.68(0.63)$ & 23.51 & 89.333 \\
$\begin{array}{l}\text { Question 5: Do you think the level of Kurdish pages, groups, and ac- } \\
\text { counts on social media covering COVID-19 is good? }\end{array}$ & $1.96(0.88)$ & 44.9 & 65.333 \\
$\begin{array}{l}\text { Question 6: Have you published any information and news related to } \\
\text { COVID-19 on social media? }\end{array}$ & $2.18(0.93)$ & 42.66 & 72.667 \\
$\begin{array}{l}\text { Question 8: Filters need to be set up for social media and a specific } \\
\text { policy followed during humanitarian crises such as the spread of the } \\
\text { COVID-19. }\end{array}$ & $2.74(0.62)$ & 22.63 & 91.333 \\
Total & $2.39(0.765)$ & 33.425 & 79.667 \\
\hline
\end{tabular}

${ }^{\mathrm{a} C O V I D-19:}$ coronavirus disease.

Table 5. Impacts of fear on study participants ( $\mathrm{N}=516)$.

\begin{tabular}{ll}
\hline Impact scale & Participants, $\mathrm{n}(\%)$ \\
\hline Psychological & $199(38.6)$ \\
Physical & $9(1.7)$ \\
Physical psyche & $47(9.1)$ \\
All of them & $75(14.6)$ \\
I was not afraid & $186(36.0)$
\end{tabular}

Participants in this study were also asked, "Which category of information has had the most impact on creating panic on social media?" As shown in Table 6, many participants $(n=137,26.6 \%)$ answered "fake news about COVID-19," and 90 (17.4\%) said it was "dissemination of the number of infections." In addition, $39(7.6 \%)$ participants chose "dissemination of the number of deaths." This indicates that fake news and misinformation have 
an immediate and massive impact on individuals during this crisis, but also factual information such as the number of cases.
The responses to Questions 3, 6, and 8 (Table 7) indicate that more males than females responded yes, neutral, and no, but in Question 5, the rate of females was higher than males for the response neutral.

Table 6. Categories of information shared on social media.

\begin{tabular}{ll}
\hline Information & Participants (N=516), $\mathrm{n}(\%)$ \\
\hline Dissemination of the number of infections (A) & $90(17.4)$ \\
Dissemination of the death toll (B) & $39(7.6)$ \\
Dissemination of fear-inducing information about COVID-19 ${ }^{\mathrm{a}}(\mathrm{C})$ & $56(10.9)$ \\
Publication of photos and videos of the cities and countries with a high number of cases (D) & $78(15.1)$ \\
Fake news about COVID-19 (E) & $137(26.6)$ \\
$\begin{array}{l}\text { Dissemination of the number of infections (A) and dissemination of the death toll (B) } \\
\text { Dissemination of the number of infections (A) and dissemination of fear-inducing information about COVID-19 (C) }\end{array}$ & $4(0.8)$ \\
$\begin{array}{l}\text { Dissemination of the number of infections (A) and publication of photos and videos of the cities and countries with a } \\
\text { high number of cases (D) }\end{array}$ & $9(1.7)$ \\
Dissemination of the number of infections (A) and fake news about COVID-19 (E) & $7(1.4)$ \\
Dissemination of the death toll (B) and dissemination of fear-inducing information about COVID-19 (C) & $3(0.6)$ \\
Other & $80(15.9)$
\end{tabular}

${ }^{\mathrm{a}}$ COVID-19: coronavirus disease.

Table 7. Some questions according to the gender of participants $(\mathrm{N}=516)$.

\begin{tabular}{lccc}
\hline Variables & Male, $\mathrm{n}(\%)$ & Female, $\mathrm{n}(\%)$ & Total, $\mathrm{n}(\%)$ \\
\hline Question 3: Do you think that publishing more news related to COVID-19a & on social media has spread fear and panic among the people? \\
No & $25(53.2)$ & $22(46.8)$ & $47(100.0)$ \\
Neutral & $36(51.4)$ & $34(48.6)$ & $70(100.0)$ \\
Yes & $233(58.4)$ & $166(41.6)$ & $399(100.0)$ \\
Question 5: Do you think the level of Kurdish pages, groups, and accounts on social media covering COVID-19 is good? & $211(100.0)$ \\
No & $144(68.3)$ & $67(31.8)$ & $113(100.0)$ \\
Neutral & $49(43.4)$ & $64(56.3)$ & $192(100.0)$ \\
Yes & $101(52.6)$ & $91(47.4)$ & $186(100.0)$ \\
Question 6: Have you published any information and news related to COVID-19 on social media? & $73(28.5)$ & $50(100.0)$ \\
No & $133(71.5)$ & $20(40.0)$ & $280(100.0)$ \\
Neutral & $30(60.0)$ & $129(46.1)$ & $433(100.0)$ \\
Yes & $151(53.9)$ & $12(24.5)$ & $12(35.3)$ \\
Question 8: Filters need to be set up for social media and a specific policy followed during humanitarian crises such as the spread of COVID- \\
19.
\end{tabular}

${ }^{\mathrm{a} C O V I D-19:}$ coronavirus disease.

According to the results shown in Table 8, the majority of Facebook users in this study were male $(n=251,58.9 \%)$ and $41.1 \%(n=175)$ were female. The majority of participants that were Instagram users were female $(n=26,78.8 \%)$, while a minority were male $(n=7,21.2 \%)$. Furthermore, of study participants that read economic news, $60 \%(\mathrm{n}=6)$ were male and $40 \%(n=4)$ were female. Finally, of the study participants that read sports news, $75 \%(n=3)$ were male and $25 \%(n=1)$ female. 
As shown in Table 9, most participants that reported using Facebook were 18-35 years of age $(n=283,66.4 \%), 124(29.1 \%)$ were $36-50$ years of age, and $19(4.5 \%)$ were 51 years or older The majority of participants that used Instagram were 18-35 years of age $(n=28,84.9 \%)$, and $5(15.2 \%)$ of those that reported using Instagram for news were $36-50$ years of age. Additionally, of those that read economic news, 4 (40\%) were 18-35 years of age, and $6(60 \%)$ were 36-50 years of age.

As shown in Table 10, 111 (37.8\%) males and 88 (39.6\%) females felt psychological fear. Of all participants that said they felt psychological fear, 135 (40.2\%) were 18-35 years of age, and $57(38.3 \%)$ were $36-50$ years of age.

Table 8. Accounting some questions according to gender of participants $(\mathrm{N}=516)$.

\begin{tabular}{|c|c|c|c|}
\hline \multirow[t]{2}{*}{ Variable } & \multicolumn{2}{|l|}{ Gender } & \multirow[t]{2}{*}{ Total } \\
\hline & Male, $\mathrm{n}(\%)$ & Female, $\mathrm{n}(\%)$ & \\
\hline \multicolumn{4}{|c|}{ Question 1: Which social media platform do you use to get news and information about COVID-19 a ? } \\
\hline Facebook & $251(58.9)$ & $175(41.1)$ & $426(100.0)$ \\
\hline Instagram & $7(21.2)$ & $26(78.8)$ & $33(100.0)$ \\
\hline Twitter & $10(58.8)$ & $7(41.2)$ & $17(100.0)$ \\
\hline Snapchat & $0(0.0)$ & $2(100.0)$ & $2(100.0)$ \\
\hline YouTube & $6(60.0)$ & $4(40.0)$ & $10(100.0)$ \\
\hline TikTok & $0(0.0)$ & $1(100.0)$ & $1(100.0)$ \\
\hline LinkedIn & $3(50.0)$ & $3(50.0)$ & $6(100.0)$ \\
\hline WhatsApp & $3(100.0)$ & $0(0.0)$ & $3(100.0)$ \\
\hline Telegram & $3(75.0)$ & $1(25.0)$ & $4(100.0)$ \\
\hline Skype & $1(100.0)$ & $0(0.0)$ & $1(100.0)$ \\
\hline Viber & 7 (77.8) & $2(22.2)$ & $9(100.0)$ \\
\hline LINE & $1(50.0)$ & $1(50.0)$ & $2(100.0)$ \\
\hline WeChat & $1(100.0)$ & $0(0.0)$ & $1(100.0)$ \\
\hline Myspace & $1(100.0)$ & $0(0.0)$ & $1(100.0)$ \\
\hline
\end{tabular}

Question 2: What news topic have you primarily heard/seen/read on social media during these three months of 2020?

$\begin{array}{llll}\text { Social news } & 12(85.7) & 2(14.3) & 14(100.0) \\ \text { Health news (COVID-19) } & 216(54.8) & 178(45.2) & 394(100.0) \\ \text { Technology news } & 2(66.7) & 1(33.3) & 3(100.0) \\ \text { Economic news } & 6(60.0) & 4(40.0) & 10(100.0) \\ \text { Sport news } & 3(75.0) & 1(25.0) & 4(100.0) \\ \text { Miscellaneous news } & 34(52.3) & 31(47.7) & 65(100.0) \\ \text { Political news } & 17(85.0) & 3(15.0) & 20(100.0) \\ \text { Cultural news } & 4(66.7) & 2(33.3) & 6(100.0)\end{array}$

${ }^{\mathrm{a} C O V I D-19:}$ coronavirus disease. 
Table 9. Accounting some questions according to age of participants ( $\mathrm{N}=516)$.

\begin{tabular}{|c|c|c|c|c|}
\hline \multirow[t]{2}{*}{ Variables } & \multicolumn{3}{|l|}{ Age, n (\%) } & \multirow[t]{2}{*}{ Total, n (\%) } \\
\hline & $18-35$ years & $36-50$ years & $\geq 51$ years & \\
\hline \multicolumn{5}{|c|}{ Question 1: Which social media platform do you use to get news and information about COVID-19 ${ }^{\mathrm{a}}$ ? } \\
\hline Facebook & $283(66.4)$ & $124(29.1)$ & $19(4.5)$ & $426(100.0)$ \\
\hline Instagram & $28(84.9)$ & $5(15.2)$ & $0(0.0)$ & $33(100.0)$ \\
\hline Twitter & $10(58.8)$ & $7(41.2)$ & $0(0.0)$ & 17 (100.0) \\
\hline Snapchat & $2(100.0)$ & $0(0.0)$ & $0(0.0)$ & $2(100.0)$ \\
\hline YouTube & $4(40.0)$ & $4(40.0)$ & $2(20.0)$ & $10(100.0)$ \\
\hline TikTok & $1(100.0)$ & $0(0.0)$ & $0(0.0)$ & $1(100.0)$ \\
\hline LinkedIn & $3(50.0)$ & $2(33.3)$ & $1(16.7)$ & $6(100.0)$ \\
\hline Telegram & $1(25.0)$ & $1(25.0)$ & $2(50.0)$ & $4(100.0)$ \\
\hline Skype & $0(0.0)$ & $1(100.0)$ & $0(0.0)$ & $1(100.0)$ \\
\hline Viber & $2(22.2)$ & $3(33.3)$ & $4(44.4)$ & $9(100.0)$ \\
\hline LINE & $0(0.0)$ & $1(50.0)$ & $1(50.0)$ & $2(100.0)$ \\
\hline WeChat & $0(0.0)$ & $1(100.0)$ & $0(0.0)$ & $1(100.0)$ \\
\hline Myspace & $1(100.0)$ & $0(0.0)$ & $0(0.0)$ & $1(100.0)$ \\
\hline \multicolumn{5}{|c|}{ Question 2: What news topics have you mostly heard/seen/read on social media during these three months of $2020 ?$} \\
\hline Social news & $9(64.3)$ & $3(21.4)$ & $2(14.3)$ & $14(100.0)$ \\
\hline Health news (COVID-19) & $266(67.5)$ & $112(28.4)$ & $16(4.1)$ & $394(100.0)$ \\
\hline Sport news & $2(50.0)$ & $2(50.0)$ & $0(0.0)$ & $4(100.0)$ \\
\hline Miscellaneous news & $41(63.1)$ & $17(26.2)$ & $7(10.8)$ & $65(100.0)$ \\
\hline Political news & $8(40.0)$ & $6(30.0)$ & $6(30.0)$ & $20(100.0)$ \\
\hline Cultural news & $3(50.0)$ & $3(50.0)$ & $0(0.0)$ & $6(100.0)$ \\
\hline
\end{tabular}

${ }^{\mathrm{a}}$ COVID-19: coronavirus disease.

Table 10. Variable description by age and gender.

\begin{tabular}{|c|c|c|c|c|c|c|}
\hline \multirow[t]{2}{*}{ Demographics } & \multicolumn{5}{|l|}{ Variable } & \multirow[t]{2}{*}{ Total, n (\%) } \\
\hline & Psychological, n (\%) & Physical, n (\%) & $\begin{array}{l}\text { Psychological and } \\
\text { physical, n }(\%)\end{array}$ & All of them, n (\%) & I was not afraid, n (\%) & \\
\hline \multicolumn{7}{|l|}{ Gender } \\
\hline Male & $111(37.8)$ & $5(1.7)$ & $24(8.2)$ & $42(14.3)$ & $112(38.1)$ & $294(100.0)$ \\
\hline Female & $88(39.6)$ & $4(1.8)$ & $23(10.4)$ & $33(14.9)$ & $74(33.3)$ & $222(100.0)$ \\
\hline Combined & $199(38.7)$ & $9(1.7)$ & $47(9.1)$ & $75(14.6)$ & $186(36)$ & $516(100.0)$ \\
\hline \multicolumn{7}{|l|}{ Age (years) } \\
\hline $18-35$ & $135(40.2)$ & $6(1.8)$ & $36(10.7)$ & $43(12.8)$ & $116(34.5)$ & $336(100.0)$ \\
\hline $36-50$ & $57(38.3)$ & $2(1.3)$ & $9(6.0)$ & $23(15.4)$ & $58(38.9)$ & $149(100.0)$ \\
\hline$\geq 51$ & $7(22.6)$ & $1(3.2)$ & $2(6.5)$ & $9(29.03)$ & $12(38.7)$ & $31(100.0)$ \\
\hline Combined & $199(38.7)$ & $9(1.7)$ & $47(9.1)$ & $75(14.6)$ & $186(36.0)$ & $516(100.0)$ \\
\hline
\end{tabular}

It is noted from Table 11 that there is a significant positive of panic about COVID-19. The total variation is equal to $75.7 \%$, statistical correlation between social media and the spreading which indicates that $75.7 \%$ of the variance of spreading panic 
about COVID-19 has been explored in social media, and the other variables $(24.3 \%)$ are due to random error. In other words, this illustrates that only $75.7 \%$ of the factors that affect spreading panic about COVID-19 are related to social media.

Table 11. Simple regression model analysis of a dependent variable (spreading panic about coronavirus disease) on the effects of social media on spreading panic about coronavirus disease and social media's impact on mental health in the Kurdistan Region of Iraq.

\begin{tabular}{|c|c|c|c|c|c|c|c|c|}
\hline \multirow[t]{2}{*}{ Model } & \multicolumn{2}{|c|}{ Unstandardized coefficients } & \multirow[t]{2}{*}{$t$ test } & \multirow[t]{2}{*}{$P$ value } & \multirow[t]{2}{*}{$R$} & \multirow[t]{2}{*}{$R^{2}$} & \multirow[t]{2}{*}{$F$ test } & \multirow[t]{2}{*}{$P$ value } \\
\hline & B & SE & & & & & & \\
\hline Constant & 0.4456 & 0.219 & 4.865 & .001 & .8701 & .757 & 95.652 & $<.001$ \\
\hline Social media & 0.6458 & 0.0588 & 11.532 & $<.001$ & $\mathrm{~N} / \mathrm{A}^{\mathrm{a}}$ & N/A & N/A & N/A \\
\hline
\end{tabular}

${ }^{\mathrm{a}}$ Not applicable.

\section{Discussion}

\section{Overview}

As media professionals working at a public university in the Kurdistan Region of Iraq, we conclude from the study results that social media has played a significant role in affecting the public during the COVID-19 crisis. The regression analysis of the study indicates that there is a significant positive statistical correlation $(R=.8701)$ between social media and spreading panic about COVID-19. Moreover, we can see that it has had a psychological effect, primarily on the younger generation, where $40.2 \%(n=135 / 336)$ of the respondents aged $18-35$ years were affected. People are gathering information from governmental sources that have eroded, and people are far more likely to get their information from social media than from any other sources. People are also unable to discern which information on social media is true and which is false, thus causing more panic and rumors about the true nature of the epidemic.

One could argue that the panic caused by widespread information about COVID-19 in the Kurdistan Region of Iraq is worse than the number of COVID-19 cases and will have a longer-lasting effect. It is important to communicate this to health professionals in the region and for media experts to work with these professionals to ensure that only well-vetted information is disseminated to the public. It is also important to engage the Ministry of Health and the Ministry of Education in this effort to be prepared for future epidemics or health situations. This pandemic has certainly helped the authors identify the need for educating consumers on health topics found through social media.

\section{Limitations}

There were various research limitations, most importantly these are self-reported data from self-selected participants, and the lockdown period was a constraint to gather more representative data. It was difficult to find participants who wished to participate in this study.

\section{Conclusions}

As media experts and educators, we have an important role to play both now and in the future of Kurdistan. We must work to educate media consumers on what constitutes good and reliable information and how to critically think through this information. Since younger people are also consuming information from social media and then spreading it to their family and friends, universities are ideal places to design courses and symposiums that can help students and faculty discern how to search for, find, and evaluate health information in the case of an epidemic or pandemic.

\section{Acknowledgments}

With the outbreak of this pandemic, the world has suffered from COVID-19. Our interest lies in the heart of developing knowledge; thus, the idea for this study was born. Here, the authors would like to extend our gratitude to everyone who was part of our research community, as their views have highly enriched our study.

In addition, we extend our acknowledgment to Dr Paiman Ahmad for reviewing this manuscript prior to submission and at the final editing phase. No funding was provided for conducting this study.

\section{Conflicts of Interest}

None declared.

\section{References}

1. World Health Organization. Coronavirus. 2020. URL: https://www.who.int/health-topics/coronavirus\#tab=tab 2 [accessed 2020-04-07]

2. NewScientist. Covid-19: the disease caused by a kind of coronavirus which first originated in Wuhan, China in late 2019 URL: https://www.newscientist.com/term/covid-19/ [accessed 2020-05-06]

3. Hernández-García I, Giménez-Júlvez T. Assessment of Health Information About COVID-19 Prevention on the Internet: Infodemiological Study. JMIR Public Health Surveill 2020 Apr 01;6(2):e18717 [FREE Full text] [doi: 10.2196/18717] [Medline: 32217507] 
4. Pappot N, Taarnhøj GA, Pappot H. Telemedicine and e-Health Solutions for COVID-19: Patients' Perspective. Telemed J E Health 2020 Apr 24:1-3. [doi: 10.1089/tmj.2020.0099] [Medline: 32329654]

5. McGowan BS, Wasko M, Vartabedian BS, Miller RS, Freiherr DD, Abdolrasulnia M. Understanding the factors that influence the adoption and meaningful use of social media by physicians to share medical information. J Med Internet Res 2012 Sep 24;14(5):e117 [FREE Full text] [doi: 10.2196/jmir.2138] [Medline: 23006336]

6. Woo H, Cho Y, Shim E, Lee J, Lee C, Kim SH. Estimating Influenza Outbreaks Using Both Search Engine Query Data and Social Media Data in South Korea. J Med Internet Res 2016 Jul 04;18(7):e177 [FREE Full text] [doi: 10.2196/jmir.4955] [Medline: 27377323]

7. Kemp S. Digital 2020: Iraq. 2020. URL: https://datareportal.com/reports/digital-2020-iraq [accessed 2020-02-18]

8. Mavragani A. Infodemiology and Infoveillance: Scoping Review. J Med Internet Res 2020 Apr 28;22(4):e16206 [FREE Full text] [doi: $\underline{10.2196 / 16206}$ [ [Medline: $\underline{32310818]}$

9. Kurdistan Regional Government. Coronavirus (COVID-19) information and advice. 2020. URL: https://gov.krd/ coronavirus-en/ [accessed 2020-04-10]

10. Chew C, Eysenbach G. Pandemics in the age of Twitter: content analysis of Tweets during the 2009 H1N1 outbreak. PLoS One 2010 Nov 29;5(11):e14118 [FREE Full text] [doi: 10.1371/journal.pone.0014118] [Medline: 21124761]

11. JMIR E-collection "Infoveillance, Infodemiology and Digital Disease Surveillance". URL: https://publichealth.jmir.org/ themes/304 [accessed 2020-03-14]

12. Hao K, Basu T. The coronavirus is the first true social-media infodemic. 2020. URL: https://www.technologyreview.com/ s/615184/the-coronavirus-is-the-first-true-social-media-infodemic/ [accessed 2020-02-12]

13. Wongkoblap A, Vadillo MA, Curcin V. Researching Mental Health Disorders in the Era of Social Media: Systematic Review. J Med Internet Res 2017 Jun 29;19(6):e228 [FREE Full text] [doi: 10.2196/jmir.7215] [Medline: 28663166]

14. Muwahed J. Coronavirus pandemic goes viral in the age of social media, sparking anxiety. URL: https://tinyurl.com/ ybnms2se [accessed 2020-03-14]

15. Gough A, Hunter RF, Ajao O, Jurek A, McKeown G, Hong J, et al. Tweet for Behavior Change: Using Social Media for the Dissemination of Public Health Messages. JMIR Public Health Surveill 2017 Mar 23;3(1):e14 [FREE Full text] [doi: 10.2196/publichealth.6313] [Medline: 28336503]

16. Brewer K. Coronavirus: How to protect your mental health. 2020. URL: https://www.bbc.com/news/health-51873799 [accessed 2020-03-16]

17. Rothschild N. Coronavirus panic sells as alarmist information flies on social media. 2020. URL: https://www.axios.com/ coronavirus-social-media-b56326b6-ab16-4c8a-bc86-e29b06e5ab2b.html [accessed 2020-03-03]

18. Cellan-Jones R. Tech Tent: Is social media spreading the virus?. 2020. URL: https://www.bbc.com/news/technology-51510196 [accessed 2020-02-14]

19. Molla R. How coronavirus took over social media. 2020. URL: https://tinyurl.com/ycwtmx3u [accessed 2020-03-12]

20. Gesser-Edelsburg A, Diamant A, Hijazi R, Mesch GS. Correcting misinformation by health organizations during measles outbreaks: A controlled experiment. PLoS One 2018 Dec 19;13(12):e0209505 [FREE Full text] [doi: 10.1371/journal.pone.0209505] [Medline: $\underline{\text { 30566485] }}$

21. Frenkel S, Alba D, Zhong R. Surge of Virus Misinformation Stumps Facebook Twitter. 2020. URL: https://www.nytimes.com/ 2020/03/08/technology/coronavirus-misinformation-social-media.html [accessed 2020-03-08]

22. Victor D. Panic and Criticism Spread on Chinese Social Media Over Coronavirus. 2020. URL: https://www.nytimes.com/ 2020/01/24/world/asia/china-social-media-coronavirus.html [accessed 2020-01-24]

23. Emmott R. Russia deploying coronavirus disinformation to sow panic in West, EU document says. 2020. URL: https:/ /tinyurl.com/yx42jzyh [accessed 2020-03-18]

24. Hernandez S. Panic spreads fear especially on social media, local doctor says. 2020. URL: https://tinyurl.com/y736nqo7 [accessed 2020-03-20]

25. The Star. Coronavirus and how social media firms are combating the spread of misinformation about the disease. 2020. URL: https://tinyurl.com/y85jagfn [accessed 2020-03-05]

26. Devlin H. Don't let coronavirus tip society into panic, say psychologists. 2020. URL: https://www.theguardian.com/science/ 2020/mar/06/dont-let-coronavirus-tip-society-into-panic-say-psychologists [accessed 2020-03-06]

27. Kent S. Fear spreads like a virus: How coronavirus panic is taking a toll on NJ's mental health. 2020. URL: https://tinyurl. com/ybwxk6o3 [accessed 2020-03-08]

28. Gold H. Inside the WHO's fight to stop false information about coronavirus from spreading. 2020. URL: https://www. wktv.com/content/news/568519502.html [accessed 2020-03-05]

29. Dillon C. Coronavirus: The psychology behind panic-buying. 2020. URL: https://tinyurl.com/y9orfutq [accessed 2020-03-11]

30. El-Terk N. Toilet paper, canned food: What explains coronavirus panic buying. 2020. URL: https://tinyurl.com/ww23bb3 [accessed 2020-03-13]

31. Garrett O. A Case of Modern Mass Hysteria? The Coronavirus. 2020. URL: https://tinyurl.com/yarx6j7r [accessed 2020-02-13]

32. Merchant RM, Lurie N. Social Media and Emergency Preparedness in Response to Novel Coronavirus. JAMA 2020 Mar 23:29-31. [doi: 10.1001/jama.2020.4469] [Medline: 32202611] 
33. La V, Pham T, Ho M, Nguyen M, P. Nguyen K, Vuong T, et al. Policy Response, Social Media and Science Journalism for the Sustainability of the Public Health System Amid the COVID-19 Outbreak: The Vietnam Lessons. Sustainability 2020 Apr 07;12(7):2931. [doi: 10.3390/su12072931]

34. Mian A, Khan S. Coronavirus: the spread of misinformation. BMC Med 2020 Mar 18;18(1):89-82 [FREE Full text] [doi: 10.1186/s12916-020-01556-3] [Medline: 32188445]

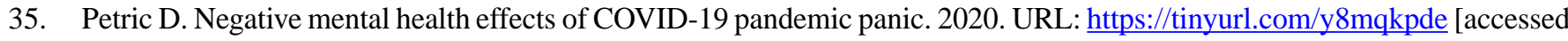
2020-04-06]

36. Shimizu K. 2019-nCoV, fake news, and racism. The Lancet 2020 Feb;395(10225):685-686. [doi: 10.1016/s0140-6736(20)30357-3]

37. Depoux A, Martin S, Karafillakis E, Bsd RP, Wilder-Smith A, Larson H. The pandemic of social media panic travels faster than the COVID-19 outbreak. J Travel Med 2020 Mar 03:1-4. [doi: 10.1093/jtm/taaa031] [Medline: $\underline{32125413]}$

38. Saud M, Mashud M, Ida R. Persistence of Social Media on Political Activism and Engagement among Indonesian \& Pakistani youths. IJWBC 2020;16(1):1 [FREE Full text] [doi: 10.1504/ijwbc.2020.10028448]

39. Mahmood QK, Saud M. Civic Participation and Facebook: A Cross Sectional Survey of Pakistani University Students. 2018 Presented at: 4th International Conference on Contemporary Social and Political Affairs (ICoCSPA) 2018; 13 August; Surabaya p. 59-65.

40. Saud M. Social Networking Sites and Deviance among Youth in Islamabad, Pakistan. EJBS 2015 May 11:48-58. [doi: 10.33422/ejbs.2018.05.85]

41. Dawson C. Activity 22: Knowing about Probability Samples. In: 100 Activities for Teaching Research Methods. London: SAGE Publications Ltd; 2016.

\title{
Abbreviations \\ COVID-19: coronavirus disease \\ KRG: Kurdistan Regional Government \\ WHO: World Health Organization
}

\author{
Edited by G Eysenbach; submitted 22.04.20; peer-reviewed by $N$ Hamassed, H Kakashekh, M Saud, MA Bahrami; comments to author \\ 30.04.20; revised version received 04.05.20; accepted 04.05.20; published 19.05.20 \\ Please cite as: \\ Ahmad AR, Murad HR \\ The Impact of Social Media on Panic During the COVID-19 Pandemic in Iraqi Kurdistan: Online Questionnaire Study \\ J Med Internet Res 2020;22(5):e19556 \\ URL: http://www.jmir.org/2020/5/e19556/ \\ doi: $\underline{10.2196 / 19556}$ \\ PMID: 32369026
}

(C)Araz Ramazan Ahmad, Hersh Rasool Murad. Originally published in the Journal of Medical Internet Research (http://www.jmir.org), 19.05.2020. This is an open-access article distributed under the terms of the Creative Commons Attribution License (https://creativecommons.org/licenses/by/4.0/), which permits unrestricted use, distribution, and reproduction in any medium, provided the original work, first published in the Journal of Medical Internet Research, is properly cited. The complete bibliographic information, a link to the original publication on http://www.jmir.org/, as well as this copyright and license information must be included. 